Радько А. О., к.е.н., провідний фахівець (ПАТ «Державний ощадний банк України»), Мельник І. Б., аспірант (Національний університет водного господарства та природокористування, м. Рівне)

\title{
ВПЛИВ ТЕХНОЛОГІЧНОГО РОЗВИТКУ НА ЗДІЙСНЕННЯ ЕЛЕКТРОННОЇ КОМЕРЦІї
}

У статті розглядається Інтернет-маркетинг як сучасний дієвий засіб просування продукції підприємства на ринку. Виділена роль засобів масової інформації в мережі Інтернет та досліджена їх популярність для здійснення електронної комерції. Показано роль смартфонів при використанні інформації з Інтернет-мережі. Обґрунтована необхідність використання інтерактивних технологій українськими виробниками для виходу на європейський ринок.

Ключові слова: Інтернет-маркетинг, електронна комерція, пошукові сайти, Інтернет-мережа, смартфон.

Постановка проблеми. Сучасна геополітична ситуація означується всеосяжною глобалізацію економіки, перерозподілом світових ринків, зміною факторів конкурентоспроможності та їі посиленням. Це вимагає від керівництва підприємств вміння своєчасно адаптуватися до змін, що здійснюються, бачити нові можливості та перспективи розвитку. Істотне значення для своєчасного пристосування до умов ринку, підвищення конкурентоспроможності підприємств та їх розвитку має використання всіх елементів комплексу маркетингу, його нових сучасних методів і технологій. При цьому відбувається розвиток теоретико-методичних засад та практичних аспектів маркетингу. Крім традиційних еволюційних концепцій маркетингу виникають нові концепції, такі, як маркетинг партнерських стосунків, маркетинг мережевої взаємодії, холістичний маркетинг та ін. Змінюються також технічні засоби, що використовуються споживачами для отримання інформації з Інтернет-мережі. Динамічність змін на сучасному інформаційному полі потребує постійного їх дослідження та моніторингу ефективності здійснення електронної комерції.

Аналіз останніх досліджень та публікацій. Дослідженням діяльності підприємств в умовах здійснення електронної комерції присвячені праці У. Балик [1], Д. Євтушенко [2], Т. Курант [3], В. чайковська [4] та ін. Проте залишаються недостатньо розробленими проблеми використання та вдосконалення інтерактивних маркетингових комунікацій підприємствами України на міжнародному ринку. 
В таких умовах маркетинг слід розглядати не просто як одну 3 функцій менеджменту, а як фундамент, на якому ґрунтується вихід підприємства на зовнішні ринки [5].

Доцільно розглядати маркетинг як філософію ведення бізнесу. Його основою є такі положення:

- маркетингові дії повинні розпочинатися й базуватися на первинних потребах організацій-покупців;

- орієнтація на клієнта повинна органічно вплітатися в дії всіх функціональних підрозділів підприємства;

- задоволення потреб організацій-клієнтів повинно розглядатися як оптимальний засіб досягнення власних довгострокових цілей задля підвищення рівня прибутковості підприємств-виробників.

Сучасне товарне виробництво має величезну кількість об'єктів і суб'єктів ринкових взаємовідносин, є складною системою взаємозв'язків та взаємозалежностей. Щоб зрозуміти всі закономірності, ринкові потреби та формування відповідної реакції на зміну маркетингового середовища, необхідно обробити великі інформаційні потоки та оволодіти сучасними інструментами ринкового аналізу. Поряд $з$ банківською, транспортною, розподільчою, комунікаційною інформаційна інфраструктура стає обов'язковим елементом забезпечення розвитку промислового маркетингу. Наше дослідження спрямоване на виявлення проблем та перспектив використання інформаційного маркетингу українськими виробниками.

В сучасних умовах маркетингова концепція розвивається, коли на ринкові суб'єкти впливають фактори зовнішнього середовища. Маркетингове макросередовище включає політичні, економічні, соціальні, демографічні, технологічні фактори. Економічні фактори включають розподіл споживчих здобутків у суспільстві та фази економічного циклу. Політичні фактори зумовлюються позиціюванням політичних сил, які забезпечують правове середовище бізнесу, стабільність економічного розвитку. Суттєвий вплив на маркетингову діяльність підприємства чинить пакет законодавчих актів, які врегульовують відносини власності, інвестиційну діяльність, монополізаційний рівень, захист суверенітету споживача, податкове середовище [6].

Мета дослідження. В сучасних дослідженнях електронної комерції вивчається багато факторів впливу на їі ефективність. Проте, надзвичайна динамічність розвитку інформаційних технологій не дозволяє визнати їх достатніми та повними. В даному дослідженні по- 
казано сучасні переваги користувачів Інтернету та зростання ролі смартфонів для розвитку Інтернет-маркетингу.

Виклад основного матеріалу. Істотне значення для своєчасного пристосування до умов ринку, підвищення конкурентоспроможності підприємств має використання всіх елементів комплексу маркетингу, його нових сучасних методів і технологій. Нині відбувається розвиток теоретико-методичних засад та практичних аспектів маркетингу. Закономірним стало впровадження Інтернет-технологій у виробничу та збутову діяльність вітчизняних підприємств для забезпечення їхньої конкурентоспроможності на ринку.

Інтернет-маркетинг є однією із сучасних тенденцій в маркетингових дослідженнях. Він передбачає застосування традиційних та інноваційних інструментів і технологій у мережі Інтернет для визначення і задоволення потреб і запитів споживачів (покупців) шляхом обміну з метою отримання товаровиробником (продавцем) прибутку чи інших вигод.

Узагальнення літературних джерел і практики діяльності підприємств та установ у віртуальному середовищі дозволяє автору систематизувати основні елементи сучасного Інтернет-маркетингу наступним чином:

- маркетингові дослідження в Інтернеті;

- маркетингові Інтернет-комунікації;

- збутова політика в Інтернеті.

В умовах інтенсивного виходу на ринок Євросоюзу ці три складові $€$ не просто взаємодоповнюючими, а виступають єдиним цілісним комплексом. Вміння створити такий комплекс та ефективно ним управляти визначає успішність підприємства.

Залежно від спектру і ефективності інтерактивних маркетингових комунікацій визначаються відповідні типи підприємств: аутсайдерів; застиглих на досягнутих результатах; тих, що знаходяться на межі кризи; тих, що рухаються уперед; лідируючих. Існують різні підходи щодо визначення місця досліджуваного підприємства в галузі інтерактивних маркетингових комунікацій. Так, наприклад, пропонується користуватись такими критеріями, як ефективність та спектр інтерактивних маркетингових комунікацій [7]. Рекомендована матриця «ринкова конкуренція/використання інтерактивних маркетингових комунікацій» будується на основі двох факторів - ступеня впливу ринкової конкуренції і рівня використання системи інтерактивних маркетингових комунікацій.

Оскільки товар - це частина комплексу інформаційного маркетингу і $є$ його основним елементом, то головним питанням маркетингової стратегії $€$ формування товарної політики, стратегії, що відпові- 
дає основним потребам споживача і $\epsilon$ необхідною умовою для досягнення повної комерційної мети підприємства у жорсткій боротьбі на українському комерційному ринку. Пріоритетними заходами маркетингу при цьому є наступні [8]:

— постійний моніторинг стану ринку збуту;

- сегментація ринку з урахуванням існуючих міжнародних квот;

- оцінка місткості ринку;

- концентрація маркетингових зусиль на тих групах продукції, які досягають європейських стандартів якості;

- повний або частковий вихід з неперспективних ринків;

- припинення виробництва та збуту продукції, що не відповідає вимогам європейського ринку;

- вибір тактики маркетингової діяльності, побудованої на заходах партизанського та вірусного маркетингу;

- вивчення вимог санітарного та фітосанітарного регулювання, що діє в ЄС;

- формування власної дилерської мережі, фірмової торгівлі для зниження транзакційних витрат, вивчення попиту споживачів, усунення надлишкових ланцюгів товарору$\mathrm{xy}$;

- використання інтернет-технологій.

- активна інноваційна політика, спрямована на створення нових видів продукції та користування перевагами нецінової конкуренції;

- залучення іноземних інвестицій для освоєння випуску конкурентоспроможної продукції;

- активна PR- підтримка та створення позитивного іміджу підприємства;

- впровадження маркетингу партнерських відносинах тощо.

Свою стратегію фірми можуть просувати різними способами. Одним з найбільш прогресивних $€$ Інтернет - ЗМІ, які охоплюють значну аудиторію (рис.). Так, найбільше охоплення аудиторії у квітні 2017 року має Інтернет-портал «tsn.ua». Великі аудиторії мають також «segodnya.ua», «bigmir.net». Меньший обсяг користувачів у «correspondent.net», «vesti-ukr.com». Проте, такий рейтинг $є$ ситуативним і змінюється постійно. Маркетологи-аналітики, як правило, вивчають місячні показники роботи сайтів і вони $є$ досить динамічними. В зв'язку з цим заслуговують на увагу дослідження компанії Alexa Internet [9]. Згідно оприлюднених нею даних, перелік найбільш 
відвідуваних сайти в України та в світі не співпадає по багатьох позиціях (табл. 1).

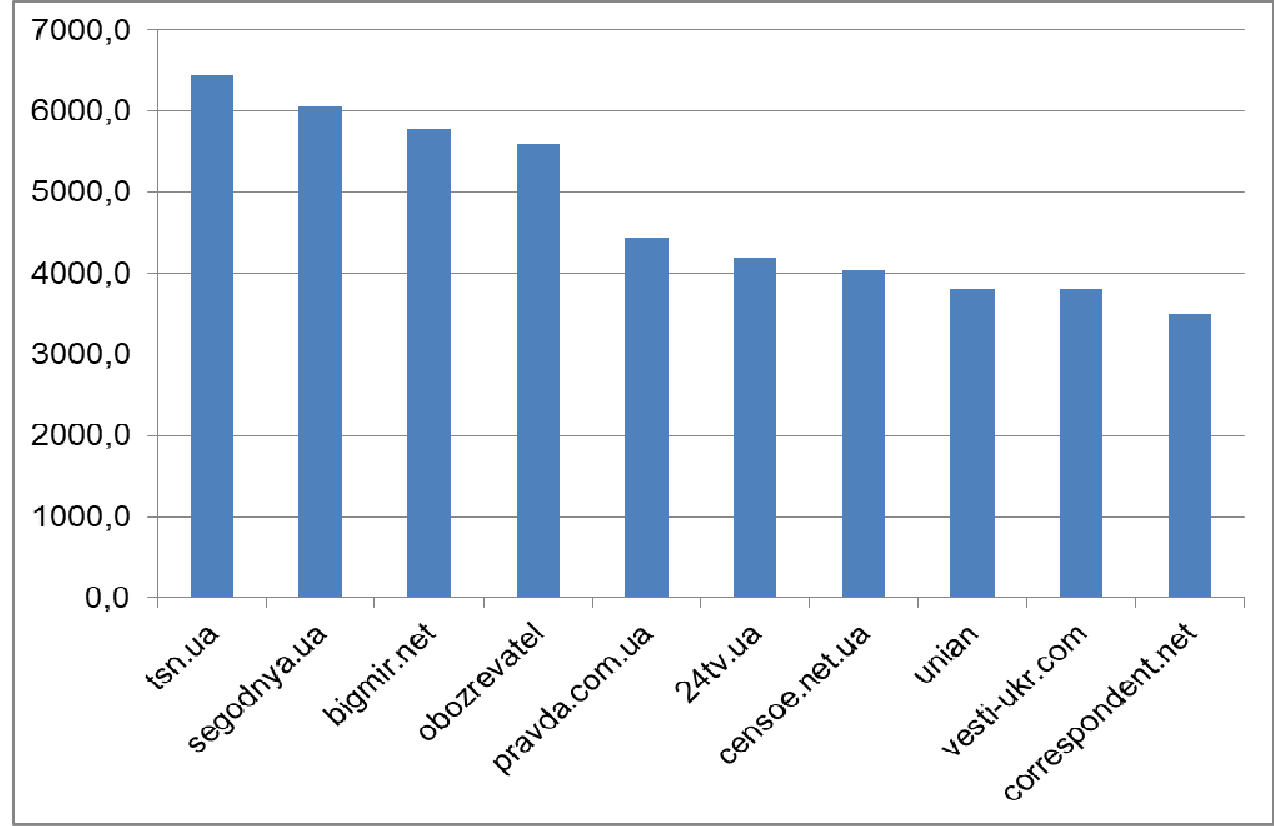

Охоплення аудиторії найбільш популярними українськими Інтернет-ЗМІ, тис. чол

Таблиця 1

Ранжування сайтів за відвідуваністю (серпень 2017)

\begin{tabular}{|c|c|c|c|}
\hline Місце & У світі & В США & В Україні \\
\hline 1 & Google.com & Google.com & Google.com.ua \\
\hline 2 & Youtube.com & Youtube.com & Youtube.com \\
\hline 3 & Facebook.com & Facebook.com & Google.com \\
\hline 4 & Baidu.com & Amazon.com & Vk.com \\
\hline 5 & Wikipedia.org & Reddit.com & Olx.ua \\
\hline 6 & Yahoo.com & Yahoo.com & Facebook.com \\
\hline 7 & Google.co.in & Wikipedia.org & Wikipedia.org \\
\hline 8 & Qq.com & Twitter.com & Ukr.net \\
\hline 9 & Reddit.com & Ebay.com & Telegraf.com.ua \\
\hline 10 & Amazon.com & Netflix.com & Rozetka.com.ua \\
\hline
\end{tabular}

Кожна країна чи регіон має свої переваги у використанні пошукових систем, що є окремою темою дослідження та має враховуватись підприємствами при здійснення електронної комерції.

Сьогодні для просування продукції в Європі необхідно використовувати інтерактивні маркетингові комунікації. Основним способом інтерактивного маркетингу $є$ Інтернет. Основними перевагами інтер- 
нет-маркетингу $€$ інтерактивність, здатність до цільового призначення, проведення пост-кліше, аналіз і т.д. Для підвищення його ефективності доцільно використовувати статистичні дані Consumer Barometer від Google [10].

Згідно проведених досліджень у 2017 році більше $80 \%$ споживачів користувались Інтернетом. При цьому в середньому 70\% респондентів щоденно користуються Інтернетом. Для просування своєї продукції в даному середовищі підприємствам важливо знати технічні засоби, що використовуються споживачами. Особливої уваги заслуговують смартфони. У 2017 році їх використовувало більше $70 \%$ споживачів (табл. 2).

Таблиця 2

Відсоток людей, які використовують смартфони для пошуку інформації в Інтернет-мережі,\%

\begin{tabular}{|c|c|c|c|c|c|c|}
\hline Роки & Німеччина & Італія & Польща & Греція & Румунія & Україна \\
\hline 2012 & 29 & 28 & 15 & 18 & 12 & 7 \\
\hline 2013 & 40 & 41 & 35 & 33 & 28 & 14 \\
\hline 2014 & 50 & 53 & 41 & 42 & 34 & 24 \\
\hline 2015 & 65 & 62 & 59 & 53 & 48 & 28 \\
\hline 2016 & 68 & 70 & 61 & 58 & 53 & 35 \\
\hline 2017 & 75 & 76 & 70 & 66 & 60 & 41 \\
\hline
\end{tabular}

В результаті зростання кількості смартфонів, відсоток людей, які мають доступ до Інтернету через них, вищий, ніж тих що використовували комп'ютер.

Ефективність Інтернет-маркетингу залежить від рівня та якості представництва у віртуальній економіці. Вона формує необхідність визначення факторів і показників, що забезпечують ефективність маркетингової комунікаційної діяльності в Інтернеті, і збільшення прибутковості коштів для просування ринку. На нашу думку, вивчення ефективності інтерактивних маркетингових комунікацій повинно починатися з діагностики веб-серверів як основного джерела інформації для потенційного покупця. При цьому важливо усвідомлювати на яких технічних пристроях буде представлена інформації про підприємство, оскільки це накладає відповідні вимоги до їі подання та оформлення.

1. Балик У. О., Колісник М. В. Електронна комерція як елемент системи світового господарства. Вісник Національного університету "Львівська політехніка". Логістика. 2014. № 811. С. 11-19. 2. Євтушенко Д. Д. Електронний бізнес, електронна комерція, Інтернет-торгівля: сутність та взаємозв'язок понять. Бізнес Інформ. 2014. № 8. С. 184-188. 3. Курант Т. Електронна комерція як спосіб задоволення попиту на онлайн-ринку. Схід. 2014. № 6. С. 19- 
Серія «Економічні науки»

Випуск 4(84) 2018 р.

24. 4. Чайковська В. П. Електронна комерція в Україні: сучасний стан та тенденції розвитку. Інтелект XXI. 2016. № 3. С. 38-48. 5. Бойчук І. В. Практика застосування маркетингу в діяльності вітчизняних промислових підприємств. Вісник ЛКА. Серія: Економічна. Випуск 22. Львів : Вид-во Львівської Комерційної Академії, 2006. 422 с. 6. Бойчук І. Значення промислового маркетингу в розвитку ринкових економічних відносин в Україні. URL: http://www.experts.in.ua/baza/analitic/index.php?ELEMENT_ID=42822 (дата звернення: 15.05.2019). 7. Шкляєва Г. О. Інтерактивні маркетингові комунікації у менеджменті підприємства. Економічний нобелівський вісник. 2014. № 1 (7). С. 509-514. 8. Ковшун Н. Е., Радько А. О. Управління інтерактивними маркетинговими комунікаціями арохолдингів України. Вісник Дніпропетровського державного аграрно-економічного університету. 2015. № 1. C. 144-150. 9. ALEXA'S MARKETING STACK. URL: https://try.alexa.com (дата звернення: 15.05.2019). 10. Consumer Barometer. URL: https://www.consumerbarometer.com (дата звернення: 15.05.2019).

\section{REFERENCES:}

1. Balyk U. 0., Kolisnyk M. V. Elektronna komertsiia yak element systemy svitovoho hospodarstva. Visnyk Natsionalnoho universytetu "Lvivska politekh-nika". Lohistyka. 2014. № 811. S. 11-19. 2. Yevtushenko D. D. Elektronnyi biznes, elektronna komertsiia, Internet-torhivlia: sutnist ta vzaiemozviazok poniat. Biznes Inform. 2014. № 8. S. 184-188. 3. Kurant T. Elektronna komertsiia yak sposib zadovolennia popytu na onlain-rynku. Skhid. 2014. № 6. S. 19-24. 4. Chaikovska V. P. Elektronna komertsiia V Ukraini: suchasnyi stan ta tendentsii rozvytku. Intelekt XXI. 2016. № 3. S. 38-48. 5. Boichuk I. V. Praktyka zastosuvannia marketynhu $v$ diialnosti vitchyznianykh promyslovykh pidpryyemstv. Visnyk LKA. Seriia: Ekonomichna. Vypusk 22. Lviv : Vyd-vo Lvivskoi Komertsiinoi Akademii, 2006. 422 c. 6. Boichuk I. Znachennia promyslovoho ma-rketynhu $v$ rozvytku rynkovykh ekonomichnykh vidnosyn $v$ Ukraini. URL: http://www.experts.in.ua/baza/analitic/index.php?ELEMENT_ID=42822 (data zvernennia: 15.05.2019). 7. Shkliaieva H. O. Interaktyvni marketynhovi komunikatsii u menedzhmenti pidpryiemstva. Ekonomichnyi nobelivskyi visnyk. 2014. № 1 (7). S. 509-514. 8. Kovshun N. E., Radko A. O. Upravlinnia interaktyvnymy marketynhovymy komunikatsiiamy arokholdynhiv Ukrainy. Visnyk Dnipropetrovskoho derzhavnoho ahrarno-ekonomichnoho universytetu. 2015. № 1. S. 144-150. 9. ALEXAS MARKETING STACK. URL: https://try.alexa.com (data zvernennia: 15.05.2019). 10. Consumer Barometer. URL: https://www.consumerbarometer.com (data zvernennia: 15.05.2019).

Рецензент: д.е.н., професор Грицюк П. М. (НУВГП)

Radko A. O., Candidate of Economics (Ph.D.), Leading Expert (Joint Stock Company State Savings Bank of Ukraine»), Melnyk I. B., Post-graduate Student (National University of Water and Environmental 
Engineering, Rivne)

\section{THE INFLUENCE OF TECHNOLOGICAL DEVELOPMENT ON THE ELECTRONIC COMMERCE ACTIVITY}

The article reflects Internet marketing as a modern and effective way to promote the company's products at the market. The role of the media in the Internet has been highlighted and their polarity has been investigated for e-commerce. It is shown the role of smartphones when using information from the Internet. The necessity of using interactive technologies by Ukrainian producers to enter the European market is proved.

Keywords: Internet marketing, e-commerce, search engines, Internet network, smartphone.

Радько А. О., к.э.н., ведущий специалист (Акционерное общество «Государственный сберегательный банк Украины»), Мельник И. Б., аспирант (Национальный университет водного хозяйства и Природопользования, г. Ровно)

\section{ВЛИЯНИЕ ТЕХНОЛОГИЧЕСКОГО РАЗВИТИЯ НА ЭЛЕКТРОННУЮ КОММЕРЧЕСКУЮ ДЕЯТЕЛЬНОСТЬ}

В статье отражен интернет-маркетинг как современный и эффективный способ продвижения продукции компании на рынке. Выделенная роль средств массовой информации в сети Интернет и исследована их популярность для осуществления электронной коммерции. Показана роль смартфонов при использовании информации из Интернет-сети. Обоснована необходимость использования интерактивных технологий украинскими производителями для выхода на европейский рынок.

Ключевые слова: интернет-маркетинг, электронная коммерция, поисковые системы, интернет-сеть, смартфон. 